\title{
真空誘導炉における湯漏れ検知システムの活用について
}

\author{
浅野 怜*，山下博司*，本庄則夫*
}

\section{Application of the Molten Metal Leak Detection System in Vacuum Induction Melting Furnace}

\author{
Rei Asano, Hiroshi Yamashita, and Norio Honjyo
}

\begin{abstract}
Synopsis
As a furnace crucible refractory of Vacuum Induction Melting (VIM) furnaces, the precasting sleeve which had not been applied for the furnace having over 3 tons capacity has been applied for 3, 6, and 9 tons VIMs in Shibukawa plant, Daido Steel Co., Ltd. in order to increase its productivity. Daido had succeeded to increase lifetime of the precasting sleeve by couples of improvements, the composition of the material particle and the chemical composition, for example. On the other hand, the detection system of molten metal leak into the furnace refractory has been equipped for general VIM as the refractory lifetime judgment system to protect the induction coil and the insulator material. However the same system had been equipped for VIMs in Shibukawa plant for long time, it had a problem in detection accuracy and this was one of the major factors of inpede to increase the furnace refractory lifetime. A new detection system was installed in August 2004 in order to resolve this problem. However, there was also some difference between the system detection and actual value of the length of molten metal leak at the refractory replacement. Results of analyzing the factor that caused the differences and evaluation of the accuracy of the new system were reported in this paper.
\end{abstract}

\section{1. 緒言}

大同特殊鋼侏啮川工場（以下，当工場と称す）の $3 \mathrm{t} ， 6 \mathrm{t}$ および $9 \mathrm{t}$ 真空誘導炉（VIM）では，生産性の向上拉よび 生産チャンスのフリー化を目的として同容量の VIM では ほとんど使用例がないプレキャスト耐火物を採用してい る. 導入当初はプレキャスト耐火物の亀裂からの湯差しを 主としたトラブルにより耐火物耐用は計画値を大幅に下 回っていたが, 耐火物粒度構成変更, 原料高品位化, 組成 変更などのプレキャスト耐火物亀裂防止対策を実施した ことで, 平均耐用は向上してきた.

一方，一般的にVIM では誘導コイルや絶縁体の損傷防 止を目的に, 湯漏孔検知装置を使用し, 耐火物の耐用限界 を判断している. 当工場でも VIM 設置当初から湯漏孔検 知装置使用しているが, その判断精度向上を目的に新たな 湯漏れ検知システムを導入した。
今回は, 新湯漏れ検知装置による湯差し測定のバラッキ の実態について調査し, 従来検知よりも高精度であること を確認した結果, プレキャストスリーブの耐用回数をさら に高めることが可能となったので以下に報告する.

\section{2. 当工場 VIM 炉体耐火物について}

\section{1 プレキャストスリーブについて}

VIM での炉体耐火物としては乾式スタンプ方式もしく はレンガ施工方式を採用するのが一般的である。しかし， 当工場では生産性向上を目的に,一体成形型プレキャス卜 耐火物（以下，プレキャストスリーブと称す）を開発・採 用してきた. Table 1 にプレキャストスリーブ適用の利点 についてまとめる。 また, Fig.1に乾式スタンプ方式とプ レキャストスリーブ方式の操業フローの比較を示す. 乾式 スタンプ方式ではスタンプ材のルッボ形状を保つための 焼結層がない，そのため, スタンプ材表面へ焼結層を形成 
する焼結溶解が必要となる。また, 焼結溶解では, 鉄製の 型枠を使用することや溶鋼の清浄度を確保できないこと から, 当工場では高品質を要求される製品の溶解は行って おらず生産性の悪化を招く一因となる。一方，プレキャス トスリーブ方式ではプレキャストスリーブが,この焼結層 の役目を果たすため, 焼結溶解が不要となり初回から製品 溶解が可能となる。

\section{2 当工場 VIM 耐火物仕様}

Table 2 に当工場の VIM 炉体耐火物諸元，Fig.2 に VIM 炉体耐火物概略図を示す。当工場 VIM 炉体耐火物はプレ キャストスリーブ，スタンプ材，コイルセメントで構成さ
れており,スタンプ材とコイルセメントの間には湯漏れ検 知装置用の電極が設置されている. VIM のコイルは $\mathrm{Cu}$ 製 パイプに冷却水が流れる構造であり,コイルに溶湯が接触 し水漏れが発生した場合, 水蒸気爆発が発生する危険があ る. 従って, VIM 耐火物の耐用安定化, および湯漏れ検 知装置による湯差し監視は安全性確保の面からも非常に 重要である。

\section{3．新湯漏れ検知装置の精度検証}

3. 1 新湯漏れ検知装置について

当工場では,このプレキャストスリーブに適した交流印

Table 1. Advantages of precasting sleeve application.

\begin{tabular}{l|l}
\hline \multicolumn{1}{c|}{ Item } & \multicolumn{1}{c}{ Advantages } \\
\hline $\begin{array}{l}\text { Furnace } \\
\text { installation time }\end{array}$ & Shorten furnace installation time by using precasting sleeve \\
\hline Sintering melt & $\begin{array}{l}\text { No need of sintering melt which is not production } \\
\text { (Sintering melt is required in dry stamp.) }\end{array}$ \\
\hline $\begin{array}{l}\text { Restrictions of } \\
\text { first charge }\end{array}$ & $\begin{array}{l}\text { No chemical composition restriction } \\
\text { (Pick up from previous melt is inevitable in dry stamp.) }\end{array}$ \\
\hline
\end{tabular}

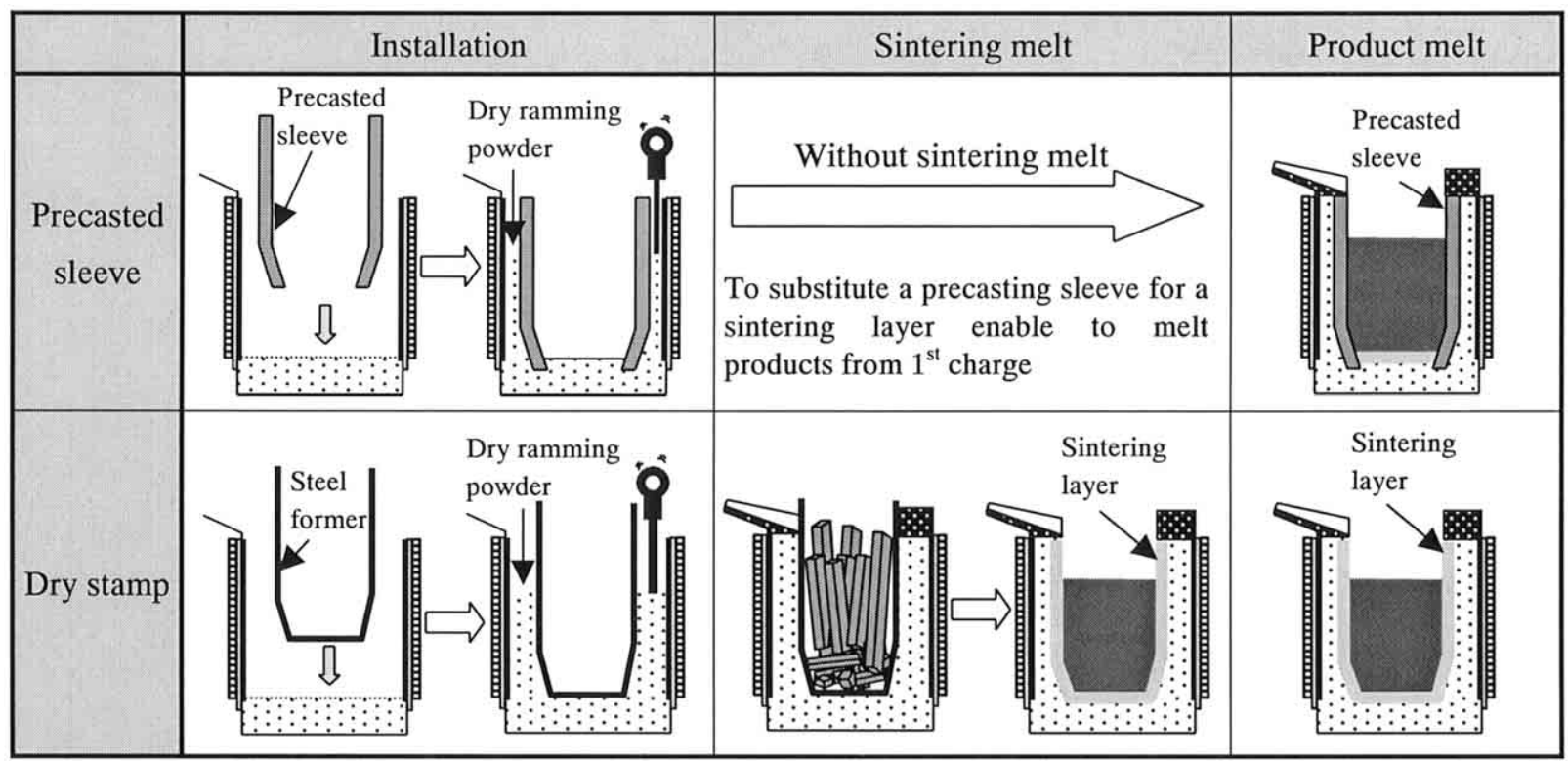

Fig.1. Difference between precasting sleeve and dry stamp operation.

Table 2. Specification of VIM refractories.

\begin{tabular}{c|c|c|c|c}
\hline \multirow{2}{*}{ Item } & \multicolumn{3}{c}{ Specification } \\
\cline { 2 - 5 } & Precasting sleeve & Back up lining & Coil grout \\
\hline \multicolumn{2}{c|}{ Function } & \multicolumn{2}{|c}{ Work lining } & Parmanent lining \\
\hline \multicolumn{2}{c|}{ Refractory } & Mono-brock & Dry ramming powder & Castable \\
\hline \multirow{2}{*}{$\begin{array}{c}\text { Composition } \\
\text { (mass\%) }\end{array}$} & $\mathrm{MgO}$ & 70 & 90 & - \\
\cline { 2 - 5 } & $\mathrm{Al}_{2} \mathrm{O}_{3}$ & 25 & 10 & 75 \\
\cline { 2 - 5 } & $\mathrm{SiO}_{2}$ & - & - & 10 \\
\hline
\end{tabular}


加式湯漏れ検知装置を 2004 年 8 月に導入した ${ }^{1)}$. Fig.3に 新湯漏れ検知装置の概略図を示す.新湯漏れ検知装置はコ

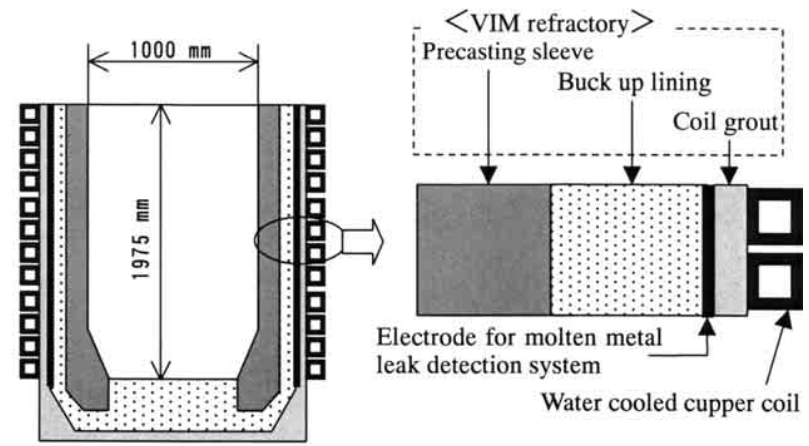

Fig.2. Schematic diagram of our VIM refractory.

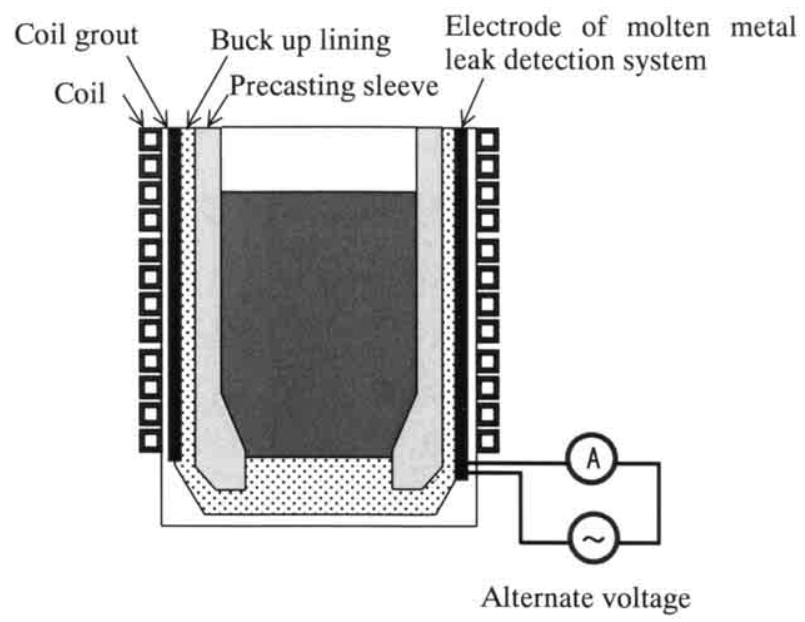

Fig.3. Schematic diagram of the new AC molten metal leak detection system.

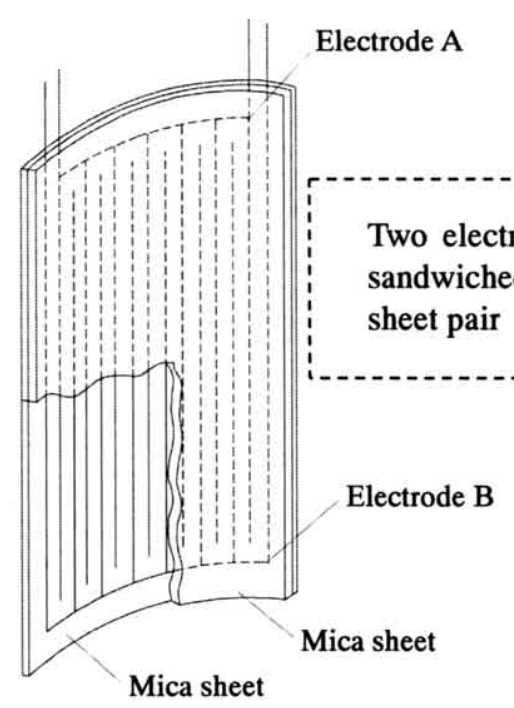

Fig.4. Schematic diagram of the electrode of the new AC molten metal leak detection system.
イルセメント前面に Fig.4 に示した検知電極を設置し, ク シ型電極 $\mathrm{A} ， \mathrm{~B}$ の間に交流電圧を印加する。この時の電流 測定の流れ方を Fig.5 に示す。耐火物の抵抗值は Fig.6に 示すように温度の上昇に伴い対数的に減少する2)ため, 電 流は温度の高い方向に流れ, もう一方の電極に戻ってくる ように流れる。従って，湯差しが進行してくると，湯差し 周辺の耐火物温度が上昇するため, 耐火物の抵抗值が下が り電流が流れやすくなる. 新湯漏れ装置はこの特性を利用 したものであり，耐火物中の電流値を連続的に測定し，湯 差し深さに換算する。なお，この時に電極 $\mathrm{A}$ と電極 $\mathrm{B}$ を 短絡して流れる電流は無視できる程度である.

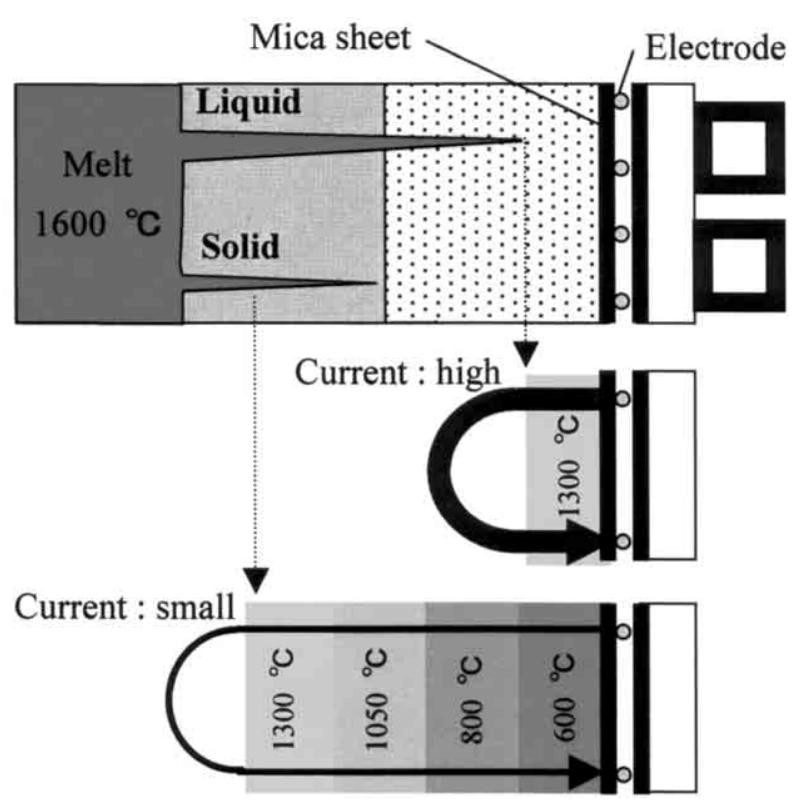

Fig.5. Model of electric current flow in the refractory.

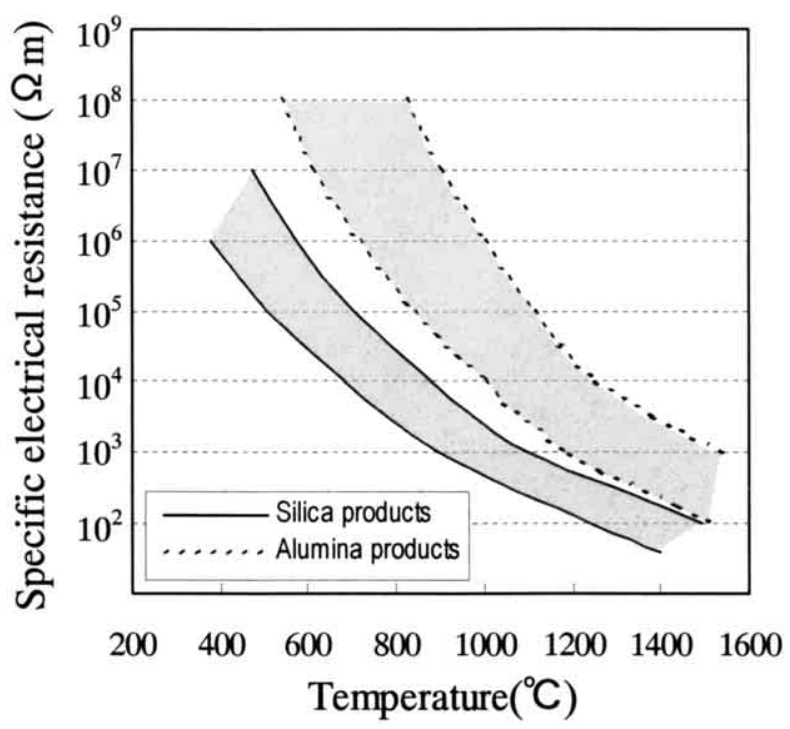

Fig.6. Relationship between temperature and specific electrical resistance of refractory materials. 
次に, Table 3 に従来の検知との相違点をまとめる. 新 湯漏れ検知装置は, 先述のような機構を有するため, 浸入 メタルが進行している（発熱あるいは溶融）部位を的確に 検知できる。しかし，Fig.7に示すように従来使用してい た検知では, 浸入メタルの進行状態（凝固 - 発熱 - 溶融) に関らずメタルが存在している部位すべてを検知するた め, 終点判定としては過敏な反応を示すケースがあった。 また, 新湯漏れ検知装置では耐火物材質に応じた周波数の 交流電圧を使用して, 耐火物に流れる交流電流值を測定す る.そのため, 同じ耐火物厚みでも新湯漏孔検知装置では
従来の湯漏孔検知装置 (直流電圧) と比較して大きな電流 が流れ，湯差しの初期段階からの測定が可能である.

\section{2 新湯漏れ検知装置による測定結果}

新湯漏孔検知装置による湯差し位置の測定結果を Fig.8 に示す.横軸は新湯漏れ検知装置による湯差し位置の測定 值であり, 縦軸は耐火物解体時の実測值である. 新湯漏れ 検知装置での耐火物残厚測定 (メタル浸入位置) に対する メーカー保証精度は土 $10 \mathrm{~mm}$ であるが，一部のデータが この精度範囲を逸脱している. 操業上問題なく使用してい たが, 更なる精度向上を目的に測定結果の検証と誤差原因

Table 3. Comparison between the conventional system and the new system.

\begin{tabular}{c|c|c}
\hline & Conventional system & New system \\
\hline Power souse & DC voltage & AC voltage \\
\hline $\begin{array}{c}\text { Measurement parameter } \\
\text { refractory }\end{array}$ & Current flowing in refractory & Detectable for hot metals only \\
\hline $\begin{array}{c}\text { Detection of penetrated metal } \\
\text { in refractory }\end{array}$ & Detect for all metals \\
\hline Other feature & $\begin{array}{l}\text { Impossible to detect a molten metal leak } \\
\text { untill the leak reach to close to a coil } \\
\text { (current in a refractory is low) }\end{array}$ & $\begin{array}{l}\text { Detectable at early stage of penetration } \\
\text { (current in a refractory higher with } \\
\text { adjusting frequency for each refractory) }\end{array}$ \\
\hline
\end{tabular}

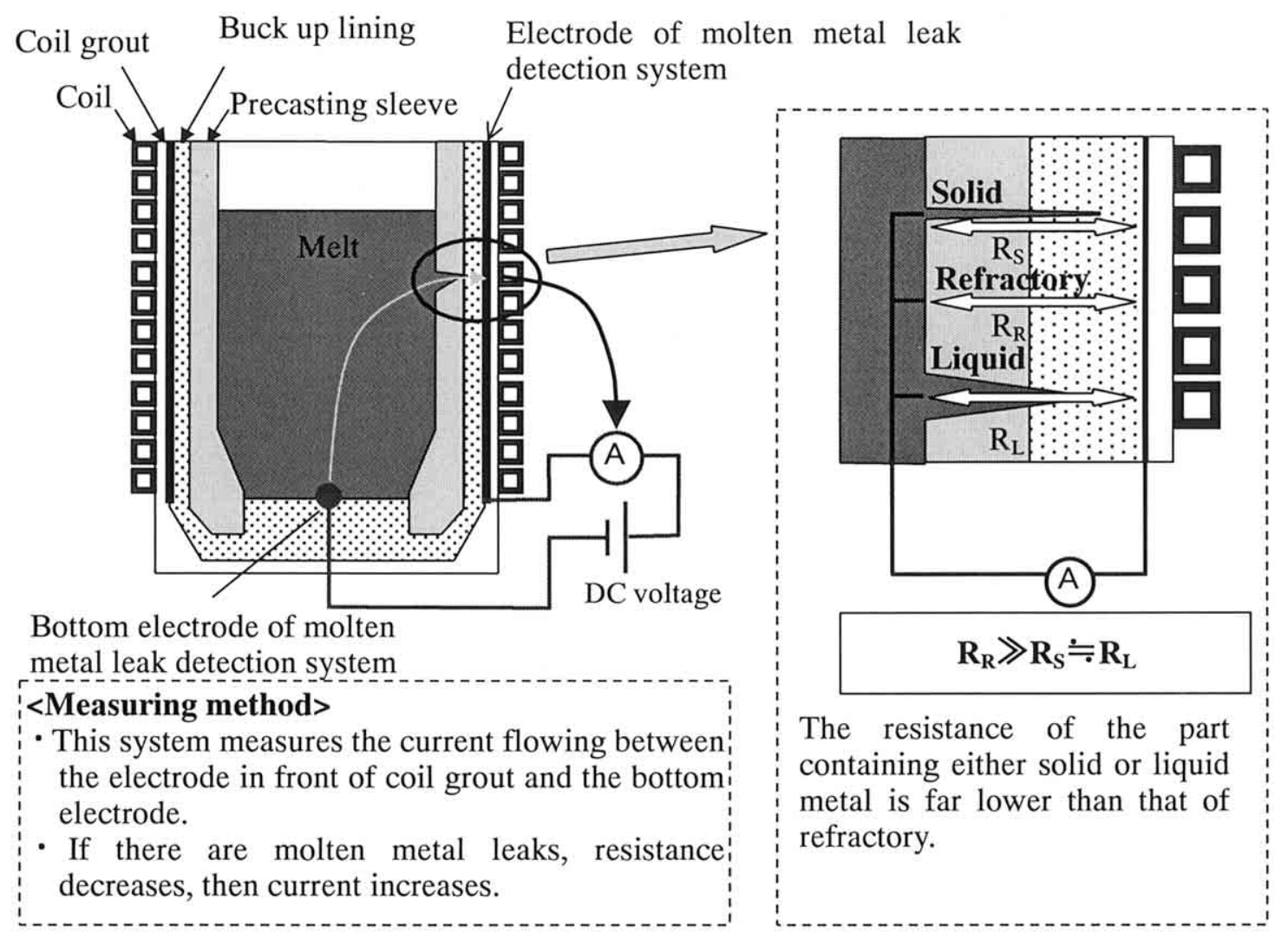

Fig.7. Schematic diagram of the conventional DC molten metal leak detection system. 
の解析を実施した。なお，マイナス側に外れたものを [ZONE - I ], プラス側に外れたものを $[\mathrm{ZONE}$ - II] とし整 理した (Fig.9).

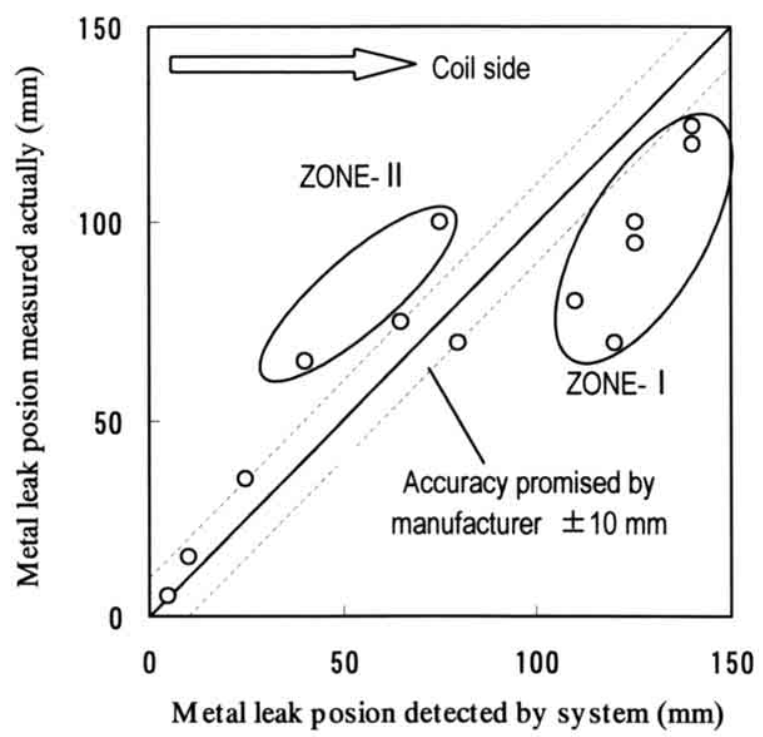

Fig.8. Result of metal leak position measurement by the new system and actual measurement after use.

\section{3 測定結果の検証}

(1) 検知測定值が実測より進行 [ZONE - I ]

ZONE - Iは, 解体後の実測值が湯漏れ検知装置で測定さ れたメタル浸入位置よりも進行していない(コイルから遠 い）ケースである. Fig.10にこれに該当する代表部位の解 体後の耐火物断面写真を示す. また, Table 4 に新湯漏れ 検知装置および目視でのメタル浸入位置測定結果とその 特徵を示す. Point A では目視できるメタルは存在しない.

\section{【ZONE- |】}

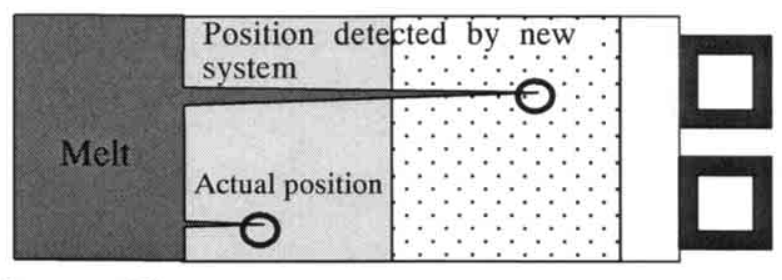

【ZONE- II】

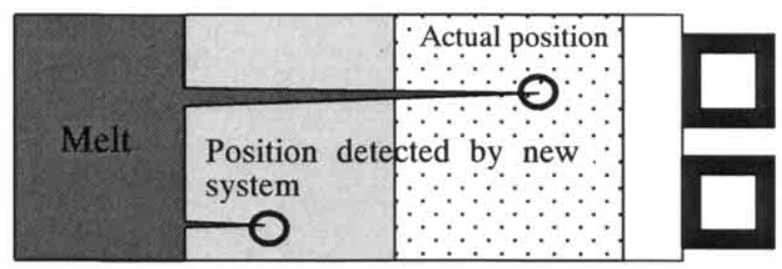

Fig.9. Molten metal leak model of ZONE - I and ZONE - II .

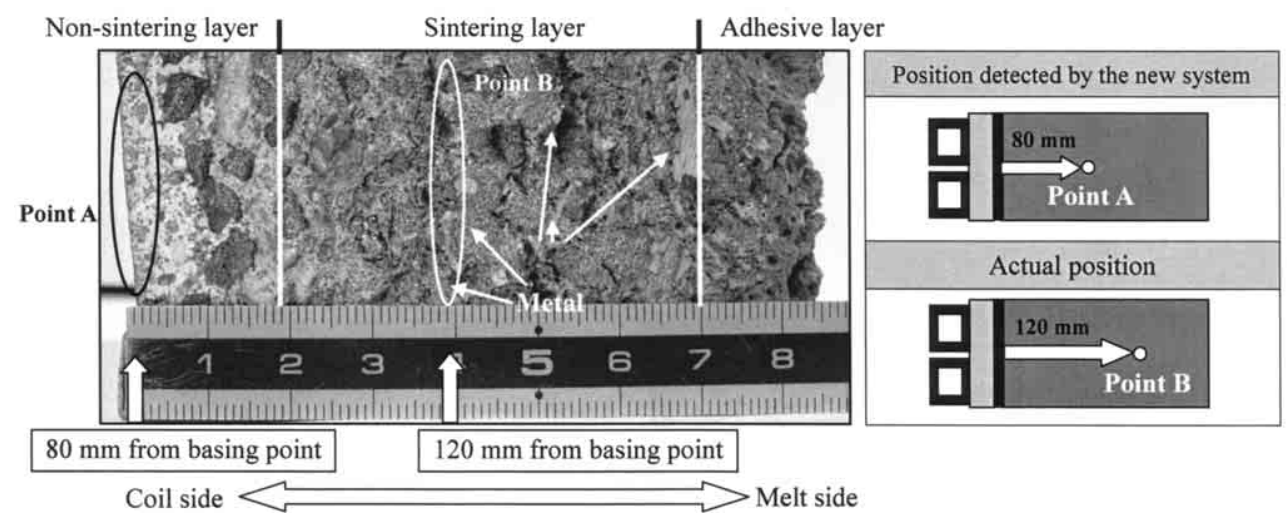

Fig.10. Cross-section photo of precasting sleeve after use.

Table 4. Feature of the positions detected by the new system and actual measurement.

\begin{tabular}{c|c|c|l}
\hline \multicolumn{2}{c|}{ Position } & $\begin{array}{c}\text { Distance from } \\
\text { basing point }\end{array}$ & \multicolumn{1}{c}{ Feature } \\
\hline A & Detected by the new system & $80 \mathrm{~mm}$ & $\begin{array}{l}\text { No metal existenceis observed, possible to observe } \\
\text { partialy sintering areas }\end{array}$ \\
\hline B & Actually observed & $120 \mathrm{~mm}$ & Sintered, some metals are observed \\
\hline
\end{tabular}


また，溶鋼からの伝熱が達していないため，ほとんど耐火 物は未焼結であるべきにも関らず, 部分的に耐火物が焼結 している。一方，Point B は溶鋼からの伝熱により全体が 焼結層となっており, さらに数 $\mathrm{mm}$ のメタル粒が存在して いる。このような状況から，目視観察のみでは Point B が 湯差し位置と判断される。しかし, Poin A での耐火物焼結 現象に着目した場合, 非磁性体である耐火物そのものが発 熱することは不可能であることから，この部位にメタルな どの磁性体が存在していたものと推定される。 そこで, Point Aの焼結部を EDX (Energy Dispersive X-ray Fluorescence Spectrometer)による定性分析を行った.その結果を Fig. 11 に示す. $\mathrm{Mn}, \mathrm{Ni}, \mathrm{Fe}$ など耐火物由来成分でない元素が大半 を占めている．中でも Mn は非常に蒸気圧が高い元素 3),4) であることから, 溶鋼成分が蒸発して耐火物中の空隙に浸 透 5) し凝集したと推察される。他の元素に関しても，Mn に付随して浸透したと考えられる. 以上の結果から, 耐火 物の空隙に浸透した溶鋼成分が凝集し, さらに誘導加熱さ れたため，目視によるメタル浸入位置 (Point B) よりも深 い位置 (Point A) が, メタル浸入位置として検知されたと
推定した.

(2) 実測が検知測定值より進行 [ZONE - II]

ZONE- Iは解体後の実測值が，湯漏れ検知装置で測定さ れたメタル浸入位置よりも進行している（コイルに近い） ケースである。これに該当する代表的部位として縦方向の メタル浸入部を Fig.12に示す。また, Table 5 にこの時の

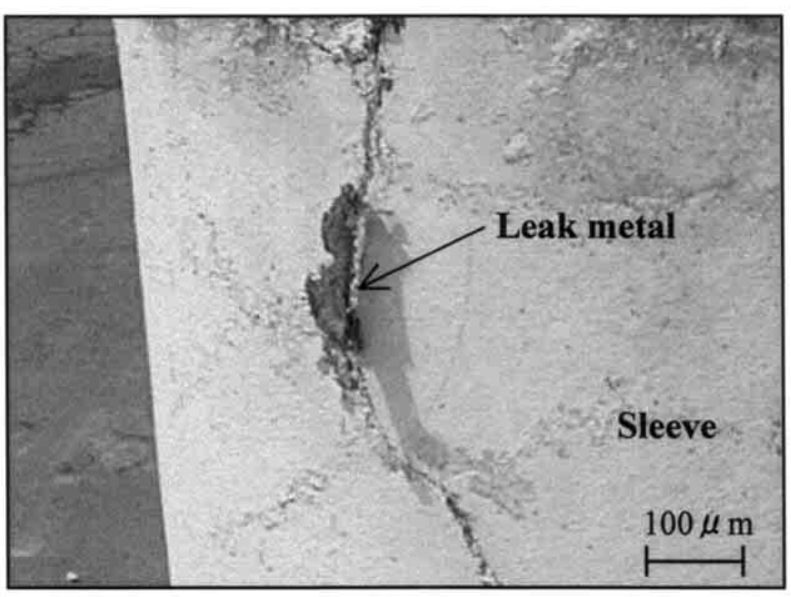

Fig.12. Photo of the leak metal in the refractory.

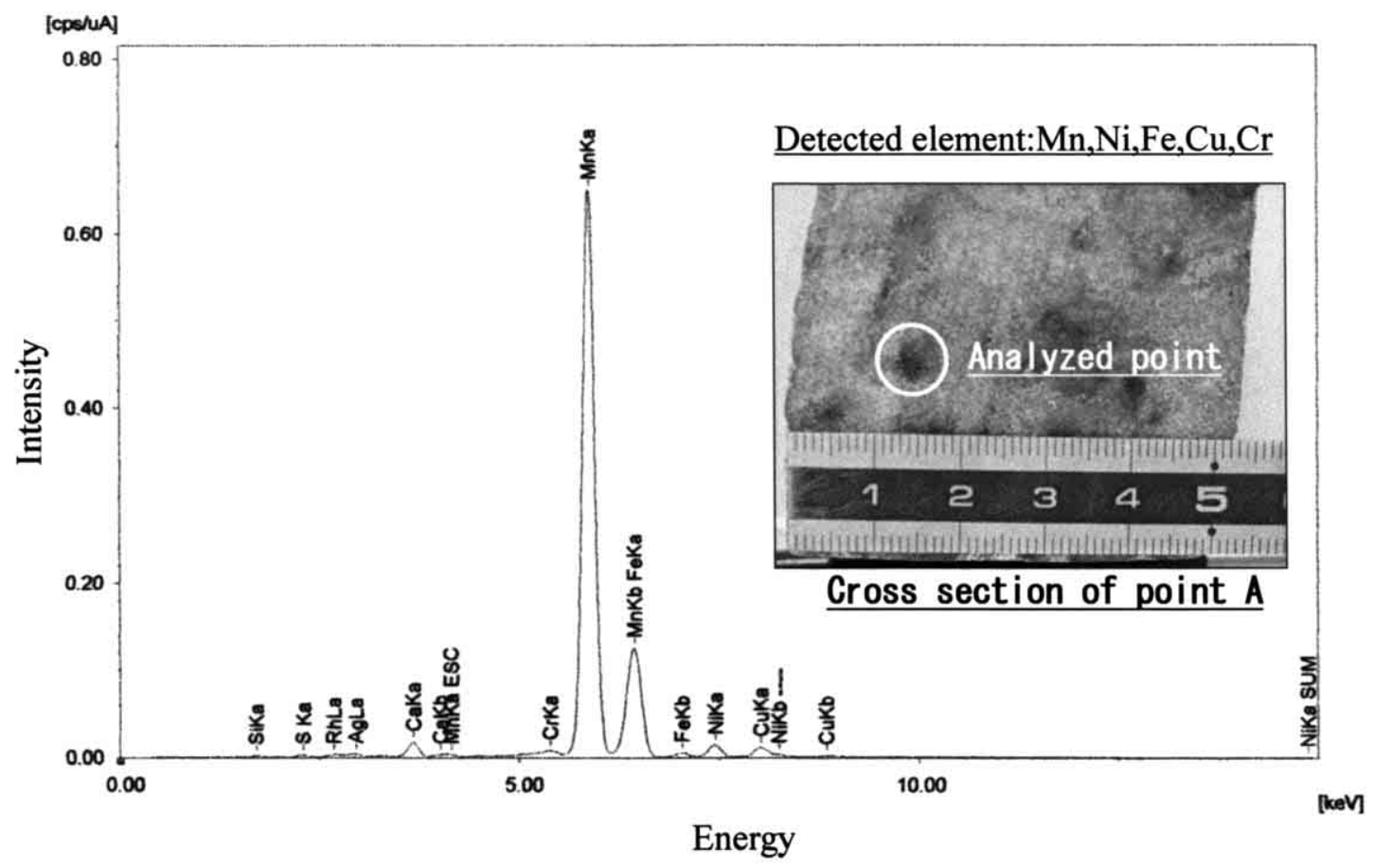

Fig.11. Result of analyzing the sintered point by EDX.

Table 5. Feature of the positions detected by the new system and actual measurement.

\begin{tabular}{c|c|l}
\hline Position & $\begin{array}{c}\text { Length from } \\
\text { basing point }\end{array}$ & \multicolumn{1}{c}{ Feature } \\
\hline Detected by the new system & Not detected & - \\
\hline Actual position & $60 \mathrm{~mm}$ & $\begin{array}{l}\text { Big leak metal } \\
\text { Refractory around the metal is not sintered }\end{array}$ \\
\hline
\end{tabular}


新湯漏孔検知装置および目視でのメタル浸入位置測定結 果とその特徽を示す.このメタルはZZONE - 1での代表例よ りも明らかに形状が大きく, VIM 稼働中に大量の湯差し が発生していたことを示しているが, メタルに接触する耐 火物に焼結反応は確認されなかった.この耐火物未焼結現 象から考えると, 浸入したメタルはそれ自身が誘導加熱さ れず発熱していない,あるいは発熱していても耐火物の焼 結温度に達しないほどの低かったものと推定され(すなわ ち安全な浸入メタルといえる)，メタルが耐火物中に浸入 しても必ずしも発熱体になるとは限らないということを 示している.今回導入した新湯漏れ装置は, 耐火物の温度 変化によって抵抗值が変動する特性を利用した検出装置 であるが, ZONE - 2のような発熱しないメタルを検知しな いことは，その測定原理から考えれば妥当な結果といえ る.

なお誘導加熱による発熱レベルは, 誘導電流の大きさや メタル自体の電気抵抗值などいくつかの要因によって変 動すると考えられる。Fig.13に $1500{ }^{\circ} \mathrm{C}$ の溶鋼が湯差しに よって耐火物内に浸入し抜熱される状況のシミュレー ション結果 ${ }^{2)}$ を示すが，浸入メタルは短時間で直ちに凝 固し, 誘導加熱はされていないことから, 耐火物との接触 による抜熱も無視できない要因となっている.

以上のように新湯漏れ検知装置でのメタル浸入位置の 測定結果は，発熱メタルの位置を忠実に示したものであ り, 目視では確認できないメタルの存在, あるいは浸入し たメタル形状による発熱レベルの差によって目視と検知 の違いが生じ, 見かけ上の誤差が発生していたと考えられ る.

\section{4. 効果}

\section{1 湯漏れ検知精度向上による効果}

コイルの溶損や絶縁劣化を防止するためには発熱する
メタルの検知精度が重要な要素となる. 旧湯漏れ検知装置 ではメタルが耐火物中に存在することのみに過敏に反応 するため, 浸入メタルの発熱挙動（真の危険性）に関らず 突発的な検知反応を示すことがあり, これが耐火物の限界 使用と安定操業の阻害要因になっていた. 今回の調査に よって新湯漏れ検知装置システムの発熱メタルに対する 検知精度と信頼性を確認したことにより，プレキャストス リーブおよびスタンプ材厚みの薄肉化を行い炉内径を拡 大した。 その結果, Fig.14 および Fig.15 に示すように耐 火物コストおよびVIM 生産性が改善した。

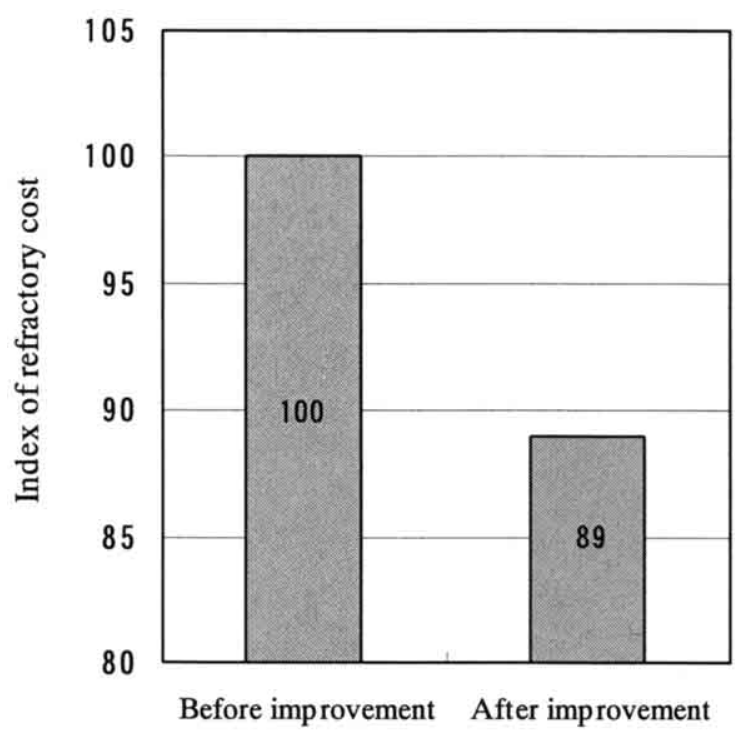

Fig.14. Productivity effect of installing the new molten metal leak detect system.

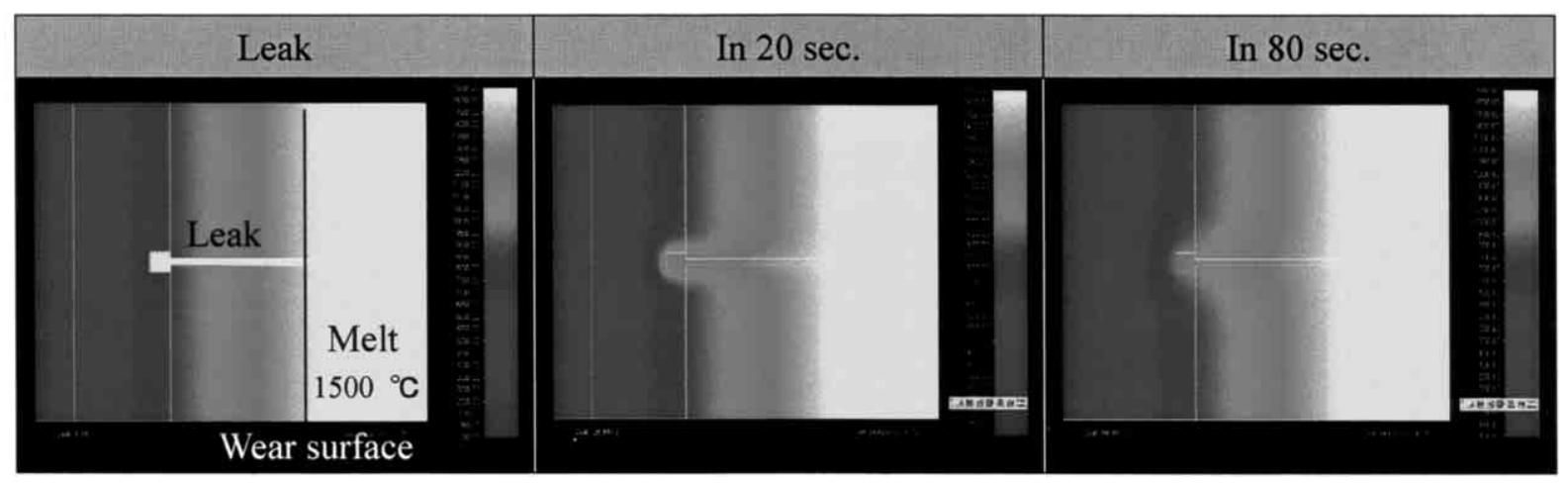

Fig.13. Simulation of solidification after molten metal leak. 


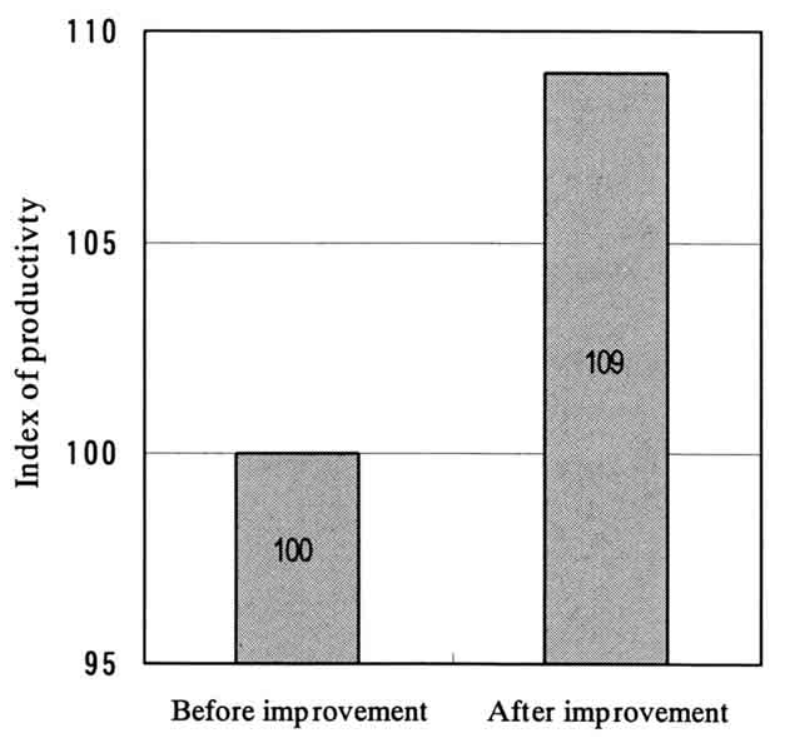

Fig.15. Cost effect of installing the new molten metal leak detect system.

\section{5. 結言}

使用後のプレキャストスリーブの実態観察の結果, 新湯 漏れ検知システムでの解体調査時のバラツキの原因は下 記によることが確認された。

(1) ZONE - I …溶鋼成分が蒸発し耐火物中に浸透した後, これらが凝集・発熱したものは検知

(2) ZONE-I…湯差しが発生したが，溶融せずに凝固し， 湯差しの進行が止まったものは非検知

いずれの場合も誤検知ではないことが確認され，耐火物 の限界使用拡大が可能となった。この結果，一炉代あたり の生産性が向上し, 耐火物コストも低減した。 今後はバッ ク材の材質改善などを図って耐火物耐用改善や生産性向 上を目指す。

$$
\text { (文 献) }
$$

1) 大同特殊鋼:日本鉄鋼協会第76回耐火物部会資料.

2) SAVEWAY社 (独):社内データ.

3）成田貴一:鉄と鋼, 57(1971), 2253.

4）日本鉄鋼協会:鉄鋼便覧, Vol. I, 175.

5）鎌倉正孝, 高木政明, 三浦茂, 石川英次郎:鉄と鋼, 62 (1976) , 1823. 